\title{
Employee Responses To Psychological Contract Breach And Violation: Intentions To Leave The Job, Employer Or Profession
}

Pascal Paillé, Laval University, Canada

Marie-Ève Dufour, Laval University, Canada

\begin{abstract}
Empirical research supports the idea that the perception of under-fulfillment of psychological contract (i.e., breach and violation) increases the willingness to leave the employer via turnover cognitions (i.e., available alternatives and search a job). Further research indicates that employee turnover is not only restricted to the notion of an employee leaving an employer to join another employer. To go beyond this restriction, data were collected among a sample of professional employees. The results suggest that when employees feel that under-fulfillment of psychological contract occur, they may leave the organization or the current job for one another by in the same organization, but did not consider leaving the profession. Findings are discussed in light of relevant literature.
\end{abstract}

Keywords: Psychological Contract; Employee Withdrawal; Turnover Cognitions; Structural Equation Modelling

\section{INTRODUCTION}

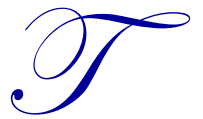

he study of employee response to psychological contract breach and violation in terms of the decision to leave the organization is a well-established research field (e.g., Dulac, Coyle-Shapiro, Henderson, \& Wayne, 2008; Fu, 2007; Orvis, Dudley, \& Cortina, 2008; Parzefall \& Hakanen, 2010; Robinson \& Morrison, 2000; Suazo, 2009; Turnley \& Feldman, 1999; Zhao, Wayne, Glibkowski, \& Bravo, 2007). However, despite these findings, some issues related to turnover cognitions have been overlooked in the literature. For example, less attention has been given to the issue of what employees do in order to resolve an unpleasant situation related to perceived PC breach or violation. Based on the literature on employee turnover, employees may prefer intra-organizational mobility (i.e. changing job for another in the same organization) or changing professions (a more radical decision). First, in order to maintain their professional and/or personal advantages, employees may look for job opportunities within their organization. Consistent with the job embeddedness literature (e.g. Lee, Mitchell, Sablynski, Burton, \& Holtom, 2004), the willingness to maintain these advantages helps to avoid the sacrifices associated with terminating the employment relationship with the organization (i.e. the employer). Second, individuals who perceive psychological contract breach or violation feel that their expectations have not been met (Turnley \& Feldman, 1999). The study by Arnold (1990) produced significant findings on the relationship between unmet expectations and career commitment ${ }^{1}$. While they did not appear to affect career commitment in the short term, unmet expectations were found to have a significant long-term negative impact. Following Arnold (1990), "although a decline in commitment had begun in the first year, it may have accelerated thereafter" (p. 300). The decision to leave the profession may help to overcome unpleasant experiences if an individual links unmet expectations with the characteristics of his/her profession. However, to date, no research has attempted to include breach, violation, perceived job alternatives, job search, intent to leave the job, intent to leave the organization, and intent to leave the profession within the same model. This study aims to fill this gap in the literature. In seeking to

\footnotetext{
${ }^{1}$ Although "career commitment" and "commitment to the profession" are different concepts (Cohen, 2003), they are often used interchangeably (Meyer, Allen, \& Smith, 1993). Arnold (1990) used Blau's (1985) scale, in which statements refer explicitly to the profession (e.g. I am disappointed that I ever entered the "...." profession). Therefore, his findings support our argument.
} 
address this issue, the study extends previous research on the effects of psychological contract on the decision to leave in two ways. First, though related, breach and violation are two different constructs. Breach reflects a cognitive evaluation, while violation reflects an affective state. Previous findings indicate that breach loses its influence on intent to leave when violation is taken into account. This study is based on the assumption that a similar pattern will emerge when turnover cognitions are included as variables. Second, previous research on the impact of PC on employee turnover has focused on employees' decision to choose extra-organizational mobility by leaving their employer. By examining intra-organizational mobility (i.e. changing job within the organization) and career change (changing profession), this study extends previous research.

\section{THEORETICAL FRAMEWORK}

\section{Psychological contract}

A psychological contract refers to a set of tacit agreements between the members of an organization and their managers and is founded on reciprocal obligations between an employer and an employee (Robinson \& Rousseau, 1994). In recent decades, the notion of psychological contract, along with the key concept of breach, has emerged as a useful explanatory framework for research on the employment relationship and individual attitudes and behaviors (Andersson, 1996; Pate et al., 2000; Rousseau, 1995). Psychological contract theory posits that individuals respond negatively when they perceive that their employer has failed to fulfill their obligations. Psychological contract breach is negatively associated with a range of individual attitudes and behaviors. Most previous studies have emphasized the effects associated with psychological contract breach. The meta-analysis by Zhao, Wayne, Glibkowski and Bravo (2007) highlighted the role of job satisfaction, organizational commitment, role performance, organizational citizenship behaviors, intention to leave and turnover. Studies have also found that psychological contract breach leads to increased cynicism (Chrobot-Mason, 2003; Johnson and O’Leary-Kelly, 2003).

In research on psychological contract breach, the terms 'breach' and 'violation' are often used interchangeably. However, over a decade ago, Morrison and Robinson (1997) made a clear distinction between the two concepts. A breach occurs when an employee feels that the employer has failed to fulfill their obligations, in proportion to the contributions made by the employee (e.g. Robinson et al., 1994; Robinson \& Rousseau, 1994). Psychological contract breach is cognitive and involves an assessment of what the employee has received compared to what s/he was promised. By contrast, violation refers to an emotional and affective state that may, under certain conditions, arise out of a belief that the employer has failed to maintain the psychological contract. According to Morrison and Robinson (1997), the two concepts are linked. A perceived psychological contract breach eventually turns into an emotional experience (i.e. violation) as a result of a cognitive interpretation. The study by Robinson and Morrison (2000) provided empirical evidence of this link.

\section{Turnover cognitions}

Turnover cognitions reflect "a mental decision intervening between an individual's attitudes regarding a job and the stay or leave decision" (Sager, Griffeth \& Hom, 1998, p. 255). Typically, turnover cognitions include a number of variables such as perceived job alternatives, job search and intention to leave the employer (i.e. the organization) (Hulin, Roznowski, \& Hachiya, 1985). These variables contribute to the employee's decision to stay or leave.

Perceived job alternatives reflect the assessment of the ease of movement (Chen, Hui, \& Sego, 1998). An individual may perceive job opportunities inside or outside the current organization. Job opportunities within the organization represent job transfer opportunities. The literature provides several definitions of job transfer, such as a permanent job reassignment within the organization with geographical relocation (Pinder \& Schroeder, 1987) or without geographical relocation (Dalton \& Todor, 1993). Beehr, Taber and Walsh (1980) described the conditions under which an employee controls his or her willingness to change jobs while remaining in the organization. Beehr et al. (1980) concluded "that the perceived mobility channels may be determined by multiple factors, including both reality and personal bias" (p. 262). Job opportunities outside the organization represent extra-organizational alternatives related (for example) to the business activity level or the number of other organizations in the immediate environment (Hulin et al., 1985). When changing jobs within the organization without geographical relocation, an employee keeps most of his/her advantages both on- and off-the-job. Following Kanfer, Wanberg, and Kantrowitz 
(2001) job search refers to a "volitional pattern of action that begins with the identification and commitment to pursuing an employment goal. The employment goal, in turn, activates search behavior designed to bring about the goal." Job search is related to devoting time and energy to finding relevant information about opportunities (Boswell, 2006). Boswell, Zimmerman and Swider (2012) identified three types of job seekers: new entrants, job losers and (unemployed and employed) job seekers. For employed job seekers, the purpose of searching for another job may be to improve employment conditions in terms of pay or status, or to exit of hardship conditions of work (Boswell et al., 2012). Finally, intent to leave the employer refers to an employee's plans to leave the organization (Bluedorn, 1982). Intention to leave is the more proximal cause of leave behavior and, as such, is often defined as the last stage before turnover (Hom, Caranikas-Walker, Prussia \& Griffeth, 1992). Considerable efforts have been made to determine how perceived job alternatives, job search and intention to leave the employer are related. Previous research on turnover psychology indicates that perceived job alternatives affect intent to leave via intent to search (Mobley, 1977). Mobley, Horner and Hollingsworth (1978), and Miller, Katerberg and Hulin (1979) found similar patterns and contributed to establishing the generalizability of the model. However, the authors called for further research on different samples. Although Mobley's model is a reference in the turnover literature, research has shown that both the type of employment and the type of industry may affect the relationships between perceived job alternatives, job search and intent to leave (Mowday, Koberg, \& MacArtur, 1984; Sager et al., 1998).

\section{$\mathrm{PC}$ and turnover cognitions}

Previous research has examined the level of psychological contract fulfillment and the decision to maintain the employment relationship. While psychological contract fulfillment has a significant positive effect on the decision to remain (Robinson \& Rousseau, 1994), under-fulfillment (i.e. violation) has a positive effect on the decision to leave the organization (e.g. Orvis et al., 2008). Zhao et al. (2007) conducted a meta-analysis to assess the influence of breach on a set of work-related outcomes. Their findings suggest that most studies have focused on the relationship between psychological breach and intention to leave the organisation. Of the 15 samples used in their paper, only four produced results linking psychological contract violation to intention to leave the organization. Zhao et al. (2007) found that psychological contract breach is strongly and positively related to turnover intentions ( $\rho$ estimated population correlated $=.42 ; \mathrm{k}=22 ; \mathrm{N}$ 6268). They also reported another interesting finding, since a strong positive relationship was found between breach and violation $(\rho$ estimated population correlated $=.52 ; \mathrm{k}=11 ; \mathrm{N} 4027)$. Finally, they used a meta-analytic correlation matrix and found a positive correlation between psychological contract violation and turnover intention $(\mathrm{r}=.62 ; \mathrm{k}=4 ; \mathrm{N}=2303)$. These results suggest that violation mediates the relationship between breach and intention to leave. Based on previous theoretical research (e.g. Morrison and Robinson, 1997), recent field studies have supported the mediating effect. Previous studies have shown that when violation is included in the regression analysis, the relationship between breach and intention to leave is less significant (Dulac et al., 2008) or non-significant (e.g., Suazo, 2009)..

There has been little research aimed at determining how specific stages of turnover cognitions (i.e. perceived alternatives and job search) occur when employees believe that their employer has failed to fulfill their obligations. As such, it would appear that the role of turnover cognitions has been less widely studied. By identifying eight factors involved in turnover decisions, Maertz and Griffeth (2004) provided insights on the effects of both psychological contract and alternatives on the motivation of an employee to stay or leave. Although Maertz and Griffeth (2004) explained how these forces are interrelated, their study focused on the interrelation between contract and alternatives. When an employer fails to fulfill his/her obligations, a breach may occur that causes the employee to reconsider the employment relationship. Although Maertz and Griffeth recognized the effect of breach on violation, the impact of violation on the decision to reconsider membership is not clear. In the event of a breach, "job alternatives may act to psychologically pull employees away from their current organization" (Maertz \& Griffeth, 2004, p. 672). To date, very few studies have reported results supporting the attractiveness of employment alternatives when employees feel that a psychological contract has not been fulfilled. For example, Robinson and Morrison (2000) found that a significant number of perceived job alternatives causes employees to be more vigilant to breach. More recently, Fu (2007) found that intra- and extra-organizational job opportunities cause employees to perceive psychological contract violations differently. First, employees perceive fewer violations when their internal employment opportunities are high than employees who perceive limited internal employment opportunities. Second, employees are more likely to perceive psychological contract violation when they have many external employment opportunities than employees who feel that they have limited external employment opportunities. 
Finally, these results suggest that perceived job alternatives may reflect a signal that breach and violation have occurred.

Few studies have provided evidence of the relationship between psychological contract under-fulfillment (breach and violation) and job search. For example, based on Hirschman's model (i.e. Exit-Voice-Loyalty-Neglect), Turnley and Feldman (1999) found a positive relationship between psychological contract violation and job search when employment alternatives are available, suggesting increased job search in response to perceived violation. Their findings also highlighted the intervening role of many job alternatives in the relationship between violation and job search. Determining whether employees want to leave their job, their employer or their profession is an important issue for assessing the consequences of psychological contract. Interestingly, Fu (2007) introduced the possibility of job transfer if internal opportunities are available. In the event of a high level of psychological contract violation, Fu's results suggest that employees prefer to move within their organization. However, in view of the method used by $\mathrm{Fu}$ (2007) to measure exit (based on a combination of three items: quit the job, conduct job search activities, and contacting outside), it is difficult to determine whether employees want to leave their job, their employer or their profession based on the results of his study. Dalton and Todor (1993) argued that "transferring (i.e. changing jobs or geographical locations, or both within an organization) may resolve dissatisfaction with various aspects of one's work as readily as changing organizations (quitting)" (p. 204). One implication is that available job opportunities within the organization can contribute to solving the issue of personal discomfort related to perceived psychological contract breach or violation. Both breach and violation generate dissatisfaction, leading in turn to a termination of the employment relationship. Based on previous findings, when an employee joins a new organization, s/he may experience personal or professional difficulties related to on- and off-the-job issues (Pinder \& Schroeder, 1987). Following Dalton and Todor (1993), employees may prefer to move within an organization (i.e. job transfer) rather than outside in order to limit negative experiences. Finally, very little research has focused on the relationship between PC and the issues related to the decision to leave the profession. Suazo et al. (2005) found a significant negative relationship between psychological contract violation and commitment to the profession. In addition, previous studies have found a negative relationship between commitment to the profession and intention to leave the profession (e.g., Flinkman et al., 2008; Meyer et al., 1993). Here, a negative relationship between psychological contract under-fulfillment and intention to leave the profession is predicted.

Based on previous research, we predict that (a) perceived job alternatives, (b) job search, (c) intention to leave the job, (d) intention to leave the organization and (e) intention to leave the profession will be better predicted by psychological contract violation than by psychological contract breach.

\section{METHOD}

\section{Sample and Data Acquisition}

The study was carried out in collaboration with the college of occupational therapists of Quebec. The reason for collecting data from a sample of occupational therapists is that the retention of this workforce "is important to ensure that occupational therapy continues as a viable profession, providing a range of services and innovative care" (Sutton \& Griffin, 2000, p. 380). Manpower shortage and high turnover remain important issues for organizations in which occupational therapists work (Lloyd \& King, 2001; Rugg, 2009). In addition, as noted by Steel and Griffeth (1989), the labor market is a heterogeneous (rather than homogeneous) construct. In view of this, the aim was to assess the impact of psychological contract breach and violation on turnover cognitions. The use of a homogeneous sample in terms of occupation is an interesting issue for determining whether employees want to leave their job, their employer or their profession when they feel that a psychological contract has not been fulfilled. The data were collected with the help of the college of occupational therapists of Quebec. The questionnaire and the ethical package (i.e., an invitation to participate explaining the overall objectives of the study, a consent form, and an information sheet designed to ensure that participation was voluntary and anonymous) were sent to a randomly selected sample of 1,000 registered occupational therapists from the college of occupational therapists of Quebec. Of these, 414 responses were returned, for a response rate of $41.4 \%$. Finally, $94.4 \%$ of the participants were female. The average age of the participants was 37.4 years $(\mathrm{SD}=8.3)$. The average organizational tenure was 9.3 years (SD $=6.7)$. 


\section{Measurement}

Psychological contract breach was measured using the 5-item scale (the first three items were reversecoded) developed by Robinson and Morrison (2000). The reliability of the scale was high $(\alpha=.91)$. Psychological contract violation was measured using the 4-item scale developed by Robinson and Morrison (2000). The reliability of the scale was high $(\alpha=.93)$. The three-item scale from Peters, Jackofsky and Salter (1981) was used to measure perceived job alternatives $(\alpha=.72)$, while the three-item scale developed by Peters et al. (1981) was used to measure intent to search $(\alpha=.83)$. The three-item scale developed by Lichtenstein, Alexander, McCarthy, and Wells (2004) was used to measure intention to leave the organization $(\alpha=.93)$. The scale used for the measurement of intent to leave the organization was also used to measure intention to leave the job. The items were adapted (e.g. there is a good chance that I will leave my current job for another in the same organization in the next year). The reliability of the scale was high $(\alpha=.82)$. The scale used for the measurement of intent to leave the organization was also used to measure intention to leave the job. The items were adapted (e.g. I will probably look for a new profession in the next year). The reliability of the scale was high $(\alpha=.83)$.

All items were measured using a 7 -point Likert scale $(7=$ strongly agree; $6=$ agree; $5=$ slightly agree; $4=$ neither agree nor disagree; $3=$ slightly disagree; 2 = disagree; and $1=$ strongly disagree).

\section{Analyses}

The two-stage process recommended by Anderson and Gerbing (1988) was followed. The first stage involves examining the measurement model, while the second stage aims to assess the research model by using structural equation modelling (SEM). For both stages, the Chi-square statistic and several other fit indices were used to examine the data. The indices included the root mean square error of approximation (RMSEA), the comparative fit index (CFI), and the non-normed fit index (NNFI). For RMSEA, the expected value is below .05 (SchermellehEngel, Moosbrugger, \& Müller, 2003). For CFI and NNFI, values above .95 are recommended (Hu \& Bentler, 1999).

\section{RESULTS}

\section{Testing for common method variance}

Because self-reports were used for all measures, it is important to test for common method variance (CMV). Podsakoff, MacKenzie, Lee, and Podsakoff (2003) indicated that the single-common-method-factor approach is appropriate when the study combines one rating source, different contexts, and an unidentified source of method bias. This widely used method (e.g., Marler, Fisher, \& Ke, 2009) involves including a common factor (latent variable) in the measurement model. Following Marler et al. (2009), items were loaded on their theoretical constructs as well as on a created latent method factor. The significance of the structural parameters was then examined both with and without this latent factor. The fit of the measurement model (see measurement model section below) and the fit of the measurement model with common factor were then compared. If the latter fits the data better than the former, we may infer that common variance bias is a threat. By contrast, if the measurement model fits the data better than the measurement model with common factor, we may infer that common variance bias is not a threat. The measurement models with method factor fitted the data well, $\chi^{2}=533.44, \mathrm{df}=229, \mathrm{p}=.000$; $\mathrm{CFI}=.94 ; \mathrm{NNFI}=.93 ; \mathrm{RMSEA}=.06$. However, the results of the Chi-square difference test (Bentler \& Bonnett, 1980 ) indicated that the measurement model provided a better fit than the measurement model with method factor, $\chi_{\text {diff }}^{2}(9)=94.1, p=.001$. Therefore, we may infer that bias due to common method variance was not a serious threat.

\section{Measurement model}

Table 1 reports the means, standard deviations, and correlations among the variables. Consistent with the method suggested by Anderson and Gerbing (1988), the first stage of the analysis was to estimate the measurement model. The results provide evidence of the reliability, convergent validity, and discriminant validity of the measures. 
Table 1 Correlation matrix

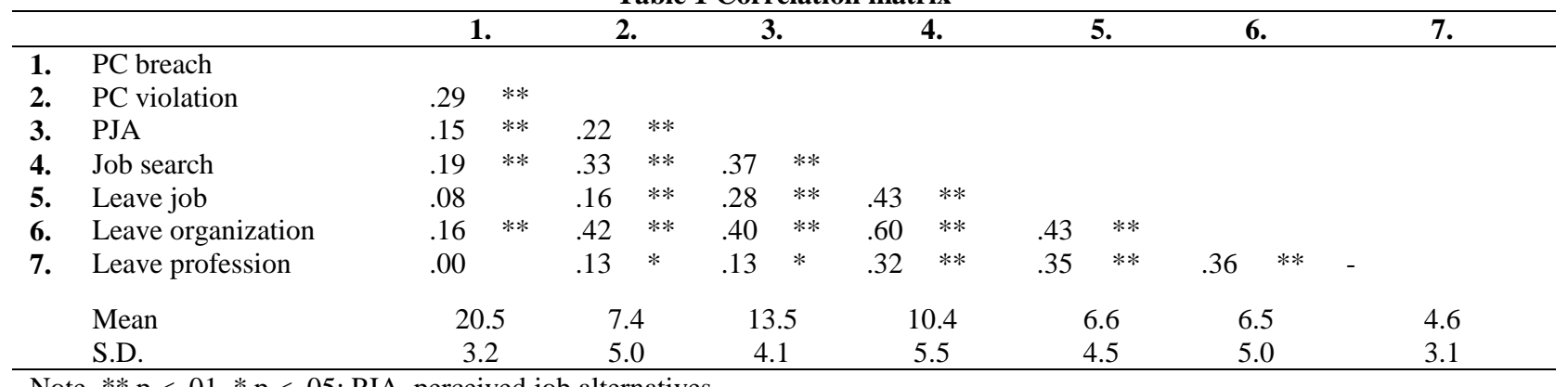

Note. $* * \mathrm{p}<.01, * \mathrm{p}<.05 ;$ PJA, perceived job alternatives.

A confirmatory factor analysis was conducted to assess the psychometric properties of the measures. The measurement model included seven factors (psychological breach and violation, perceived job alternatives, job search, intention to leave the current job, intention to leave the employer, and intention to leave the profession) and provided an excellent fit to the data, $\chi^{2}=439.26$, df $=288, \mathrm{p}<.000 ; \mathrm{CFI}=0.96$; NNFI $=0.95 ; \mathrm{RMSEA}=.05$. All indicators load significantly $(\mathrm{p}=.001)$ on their respective constructs. The results provide evidence of convergent validity.

Composite reliability or CR (which estimates the extent to which a set of latent construct indicators share in their measurement of a construct), average variance extracted or AVE (the proportion of total variance explained by the latent variable), and Jöreskog's $\rho$ are used for assessing the Measurement model. Hair, Anderson, Tatham and Black (1998) recommended threshold values for CR and AVE above 0.70 and 0.50, respectively. Fornell and Larker (1981) recommend that Jöreskog's $\rho$ should be above the 0.70 threshold. Following Fornell and Larker (1981) and Hair et al. (1998), the CR values are ranged from .80 (perceived job alternatives) to .95 (PC-violation), and the AVE values from .52 (perceived job alternatives) to .80 (intention to quit the employer). In addition, Jöreskog's $\rho$ are ranged from .75 (perceived job alternatives) to .92 (PC-violation). Therefore, for each construct, internal consistency was satisfactory.

\section{SEM}

The second stage was to use SEM. Using AMOS (Arbuckle, 2009), the model tests were based on the covariance matrix and were estimated using maximum likelihood estimation. The research model fitted the data well, $\chi^{2}=370.76$, df $=232, \mathrm{p}=.000 ; \mathrm{CFI}=.97 ; \mathrm{NNFI}=.97$; RMSEA $\left.=.04\right)$. To eliminate the possibility of one or more nested models that might have shown a better fit and led to the rejection of the research model (James, Mulaik, \& Brett, 2006), the research model was compared to several competing models. The competing models were developed by adding paths successively (a) from both psychological contract violation and breach to job search (model 2), (b) from both psychological contract violation and breach to intention to leave the current job for another in the same organization (model 3), (c) from both psychological contract violation and breach to intention to leave the employer (model 4), and (d) from both psychological contract violation and breach to intention to leave the profession (model 5). The baseline comparison was based on the Chi-square difference test (Bentler and Bonnett, 1980) and the Akaike's Information Criterion (AIC), for which a small value is expected (Hu and Bentler, 1999). Table 2 shows the results of the comparison. Based on the Chi-square difference test and the AIC, Model 2 was the best-fitting model. Thus, following James et al. (2006), because it was more parsimonious, Model 2 has been retained.

While psychological contract breach was positively related to psychological contract violation $(\beta=.564$, student $\mathrm{t}=10.254, \mathrm{p}=.000)$ and perceived job alternatives $(\beta=.226$, student $\mathrm{t}=2.828, \mathrm{p}=.005)$, no significant relationship was found with job search $(\beta=.062$, student $t=0.904$, ns). Psychological contract violation was positively related to perceived job alternatives $(\beta=.191$, student $t=2.379, \mathrm{p}=.017)$ and job search $(\beta=.251$, student $\mathrm{t}=2.455, \mathrm{p}=.014)$. Perceived job alternatives was positively related to job search $(\beta=.496$, student $\mathrm{t}=$ $6.171, \mathrm{p}=.000)$. Finally, job search was positively related to intention to leave the current job $(\beta=.481$, student $\mathrm{t}=$ $6.734, p=.000)$, intention to leave the organization $(\beta=.628$, student $t=11.710, p=.000)$, and intention to leave the profession $(\beta=.389$, student $t=6.137, \mathrm{p}=.000)$. 


\section{DISCUSSION}

\section{Findings}

The study aimed to determine how psychological contract and turnover cognitions are related by including under-fulfillment (i.e. breach and violation), perceived job alternatives, intention to search for a job, and intentions to leave the current job, the organization, and the profession within the same model. The aim was first to disentangle the relationship between psychological contract and decision to leave by assessing the influence of the variables involved in turnover cognitions, and second to focus on employees who feel that a psychological contract underfulfillment (breach and violation) has occurred. Overall, the findings indicate that violation rather than breach is a better predictor for most turnover cognitions. Holtom, Mitchell, Lee and Eberly (2008) argued that the decision to leave could be better predicted by determining whether employees want to leave their job, their employer or their profession. This study provides further evidence of the specific issue of what employees are seeking to change or avoid when they perceive psychological contract under-fulfillment.

Table 2 Results of model comparisons (PC and turnover cognitions)

\begin{tabular}{|c|c|c|c|c|c|c|c|c|}
\hline Models & $\chi^{2}$ & df & $\chi^{2} / \mathbf{d f}$ & GFI & CFI & NNFI & RMSEA & AIC \\
\hline Null model & $5756.33 * * *$ & 276 & 20.85 & - & - & - & - & - \\
\hline Research model & $370.76 * * *$ & 232 & 1.59 & .91 & .97 & .97 & .04 & 506.7 \\
\hline $\begin{array}{l}\text { Model 2: adding paths from both PCV } \\
\text { and breach to job search }\end{array}$ & $358.88 * * *$ & 230 & 1.56 & .91 & .97 & .97 & .04 & 498.8 \\
\hline $\begin{array}{l}\text { Model 3: adding paths from both PCV } \\
\text { and breach to intention to leave the } \\
\text { current job }\end{array}$ & $358.30 * * *$ & 228 & 1.57 & .91 & .97 & .97 & .04 & 502.3 \\
\hline $\begin{array}{l}\text { Model 4: adding paths from PCV and } \\
\text { breach to intention to leave the employer }\end{array}$ & $357.21 * * *$ & 226 & 1.58 & .91 & .97 & .97 & .04 & 505.2 \\
\hline $\begin{array}{l}\text { Model 5: adding paths from both PCV } \\
\text { and breach to intention to leave the } \\
\text { profession }\end{array}$ & $356.11 * * *$ & 224 & 1.58 & .91 & .97 & .97 & .04 & 508.1 \\
\hline
\end{tabular}

By providing original data showing that violation increases the number of perceived job alternatives, followed by an increased tendency to engage in job search, and leading finally to the intention to leave the organization, the results of this study are not consistent with previous studies that found positive relationships between breach and intention to leave the organisation (e.g. Orvis et al., 2008), breach and perceived job alternatives (e.g. Fu, 2007), and breach and job search (e.g. Turnley \& Feldman, 1999). Two factors may account for these results. First, as noted by Zhao et al. (2007), unlike breach, there has been far less research on violation. By only measuring breach, it seems reasonable to assume that the role of psychological contract breach has been overemphasized in previous studies. Recent findings by Suazo (2009) support this idea. Among other objectives, Suazo (2009) assessed the mediating role of violation in the relationship between breach and intention to leave the organization. Concerning only breach, Suazo reported a significant positive effect on intention to leave. By including violation in the regression, breach became non-significant, indicating a full mediating effect on the relationship between breach and intention to leave. Finally, the results of this study are consistent with Suazo's (2009) findings. Secondly, the results can be explained by the difference between breach and violation. Whereas breach results from a perceived discrepancy between promise and fulfillment, violation reflects an emotional response to the identification and interpretation of a breach (Conway \& Briner, 2002). Following Robinson and Morison (2000), "in the specific case of psychological contract breach, employees will experience more intense feelings of violation following a perceived breach if they attribute it to reneging rather than to incongruence (i.e. misunderstanding)" (p. 532). By applying this idea to the decision to leave, the implication is that if employees feel that breach is less problematic than violation, the perception of a breach will not trigger a willingness to leave, unlike a perceived violation.

A number of other significant results emerged from the study. While no effect was found for breach, violation was found to influence the decision to leave the current job while remaining in the same organization. The study is the first to report this relationship. As noted above, given the measurements made by Fu (2007), it was 
difficult to determine whether the intention of the employees was to leave their organisation or their job. These results extend the findings of the study by $\mathrm{Fu}$ (2007). By reporting a significant positive relationship between violation and intention to leave the current job, this study suggests that employees do not attribute the cause of under-fulfillment solely to the organization. It seems plausible to assume that some employees attribute underfulfillment to their leaders. The willingness to transfer may imply that employees want to resolve the issue of violation due to poor managerial skills if intra-organizational opportunities are available. In addition, changing job while remaining in the same organization enables employees to maintain some personal advantages if they are embedded for off-the-job related reasons. In this case, consistent with the unfolding model (Lee et al., 2004), employees avoid major sacrifices such as leaving the community (e.g. place, family, neighborhood, etc.). Finally, if intra-organizational opportunities are not available, rather than changing jobs in the same organization, employees may decide to leave the organization.

The results indicate that a perceived breach of the psychological contract and the resulting feeling of psychological contract violation do not undermine the sense of belonging to the profession since the study found no significant relationship between psychological contract and intention to leave the profession. Therefore, it seems reasonable to assume that employees are more likely to attribute a perceived breach to the organizational context in which they work than to their profession. The literature on professional affiliation may help to understand this result. The sense of belonging to the profession may help an employee to overcome difficulties associated with a particular employment context.

\section{Practical Implications}

Based on previous research, managers know that the cognitive dimension (i.e. breach) of psychological contract under-fulfillment causes an emotional response (i.e. violation). The effect of breach on work outcomes via violation has been explained in terms of a translation process (Raja et al., 2004). Much has been said about how to avoid a perceived breach. Using communication tools (Suazo, 2009), training in emotion regulation (Bordia, Restubog, \& Tang, 2008), helping employees to make sense of critical events (Parzefall \& Coyle-Shapiro, 2011) or offering innovative employment options (Bellou, 2009) are just some of the ways of reducing this perception. The results of this study suggest that job search activity increases the decision to leave the current job for another in the same organization or to leave the organization for another. Thus, increased job search may be an indication that a psychological contract has not been fulfilled. Employee turnover is costly. Phillips and Connell (2003) showed the negative impact of turnover on the organization (e.g. workflow interruptions, financial loss, wasted efforts, etc.) and on leavers (e.g. loss of employee benefits or job seniority, loss of social network, etc.). Our results suggest that, provided job opportunities are available, changing jobs in the same organization is a solution for resolving the sense of discomfort related to a breach or violation of the psychological contract. Given the costs associated with the decision to terminate the employment relationship, employers could use intra-organizational mobility as a strategy to retain employees.

\section{LIMITATIONS OF THE STUDY AND FUTURE RESEARCH}

Despite its contributions, this study has three main limitations. First, for the needs of the study, a specific occupation affected by shortage was targeted (occupational therapists), thus potentially limiting the generalizability of the results. Second, although common method variance was not shown to be a serious threat to the results of this study, given the cross-section design used in the present study, relationships among the variables should be taken with cautions. Third, because breach was assessed based on an overall measurement, no specific dimension was used to determine the potential impact on turnover cognitions via violation.

Future studies will need to address these limitations. First, future research should replicate these findings by surveying other occupations and less specific samples. Second, future research should focus on individual characteristics (e.g. gender, age, etc.) as potential moderators. For example, Bellou (2009) found that women and men did not consider the 'same contents of psychological contract' and that young employees are more likely to accept breach and violation than older employees. It would be interesting to examine how these differences affect the relationship between psychological contract, turnover cognitions and decision to leave. Third, future studies could add other behavioral reactions to psychological contract under-fulfillment. For example, while previous 
findings showed that psychological contract under-fulfillment affects the willingness to engage in organizational citizenship behaviors (OCBs) (Turnley, Bolino, Lester, \& Bloodgood, 2003), other studies have shown that organizational citizenship behaviors and the decision to leave are negatively related (Paillé \& Grima, 2011). These results raise the issue of the potential mediating role of OCBs in the relationship between psychological contract breach and violation and employee retention.

\section{CONCLUSION}

While the effects of psychological contract breach and violation on intention to leave are well-documented, less attention has been given to other exit options, such as intention to leave the current job for another in the same organisation and intention to leave the profession. This study was designed to improve our understanding of employee response to psychological contract under-fulfillment (changing job, changing employer or changing profession). The findings indicate that employees only consider extra-organizational mobility (leaving the organization for another) and intra-organizational mobility (leaving the current job for another in the same organization) as exit options. By contrast, the decision to leave the profession is not affected by perceived psychological contract under-fulfillment. Although more research is needed, by including breach, violation, perceived job alternatives, job search, intention to leave the job, intention to leave the organization, and intention to leave the profession in the same model, this study improves our understanding of employee response to perceived psychological contract under-fulfillment.

\section{AUTHOR INFORMATION}

Pascal Paillé, Dr., is a Full professor of Human Resource Management at Laval University in Québec, Canada. His research interests are exchange social theory, organisational citizenship behaviour, withdrawal behaviour, and green behaviors at work. His research appears in the Journal of Business Ethics, International Journal of Human Resource Management, Journal of Social Psychology, International Journal of Organizational Theory and Behavior, Journal of Psychology, etc. He is Head of Employee Retention Group Research. E-mail: pascal.paille@fsa.ulaval.ca (Corresponding author)

Marie-Eve Dufour Ph.D, is an Assistant professor of Human Resource Management at the Faculty of Business Administration of Laval University. Her primary research interest areas include career management and psychological contract, older worker's management, employee voice and silence and person-organization fit. She is a member of the Employee Retention Group Research. E-mail: marie-eve.dufour@fsa.ulaval.ca

\section{REFERENCES}

1. Anderson, J.C., and Gerbing, D.W. (1988). Structural Equation Modeling in Practice: A Review and Recommended Two-Step Approach. Psychological Bulletin, 103, 411-423.

2. Andersson, L.M. (1996). Employee cynicism: An examination using a contract violation framework. Human Relations, 49, 11, 1395-1418.

3. Arbuckle, K. (2009). Amos 5.0. Update to the Amos. User's Guide. Chicago. IL: SmallWaters Corporation.

4. Arnold, J. (1990). Predictors of Career Commitment: A Test of Three Theoretical Models, Journal of Vocational Behavior, 37, 285-302.

5. Beehr, T. A., Taber T. D. \& Walsh, J. T. (1980). Perceived Mobility Channels: Criteria for Intraorganizational Job Mobility. Organizational Behavior and Human Performance, 26, 250-264.

6. Bellou, V. (2009). Profiling the desirable psychological contract for different groups of employees: evidence from Greece. The International Journal of Human Resource Management, 20, 4, 810-830

7. Bentler, P.M., \& Bonnett, D.C. (1980). Significance tests and goodness of fit in the analysis of covariance structures. Psychological Bulletin, 80, 588-506.

8. Blau, G. (1985). The measurement and prediction of career commitment. Journal of Occupational Psychology, 58, 277-288.

9. Bluedorn, A. C. (1982). A unified model of turnover from organizations. Human Relations, 35, 135-153. 
10. Bordia, P., Restubog, S. L. D. \& Tang, R. L. (2008). When Employees Strike Back: Investigating Mediating Mechanisms Between Psychological Contract Breach and Workplace Deviance. Journal of Applied Psychology, 93, 5, 1104-1117.

11. Boswell, W. R. (2006). Job search. In S. G. Rogelberg (Ed.), Encyclopedia of industrial/organizational psychology (pp. 414-416). Thousand Oaks, CA: Sage.

12. Boswell, W. R., Zimmerman, R.D. \& Swider, B. W. (2012). Employee Job Search: Toward an Understanding of Search Context and Search Objectives. Journal of Management, 38, 1, 129-163.

13. Chen X.-P., Hui C., \& Sego D.J. (1998). The Role of Organizational Citizenship Behavior in Turnover: Conceptualization and Preliminary Tests of Key Hypotheses. Journal of Applied Psychology, 83, 6, 922931.

14. Chrobot-Mason, D.L. (2003). Keeping the promise: Psychological contract violations for minority employees. Journal of Managerial Psychology, 18, 1, $22-45$.

15. Cohen, A. (2003). Multiple Commitments in the Workplace: An Integrative Approach. Mahwah, NJ: Lawrence Erlbaum Associates.

16. Conway, N. \& Briner, R. B. 2002. A daily diary study of affective responses to psychological contract breach and exceeded promises. Journal of Organizational Behavior, 23, 287-302.

17. Dalton, D., \& Todor, W. (1993). Turnover, Transfer, Absenteeism: An Interdependent Perspective. Journal of Management, 19, 2, 193-219.

18. Dulac, T., Coyle-Shapiro, J.A.-M, Henderson, D.J. \& Wayne, S.J. (2008). Not all responses to breach are the same: The interconnection of social exchange and psychological contract processes in organizations. Academy of Management Journal, 51, 1079-1098.

19. Flinkman M., Laine M., Leino-Kilpi H., Hasselhorn H.-M. \& Salanterä S. (2008). Explaining young registered Finnish nurses' intention to leave the profession: a questionnaire survey. International Journal of Nursing Studies, 45, 727-739.

20. Fornell, C., \& Larker, D.F. (1981). Evaluating structural equations models with unobservable variables and measurement error. Journal of Marketing Research, 18, 39-50.

21. Fu, C.J. (2007). Psychological Contract Violations and Employees' Work Behavior Reactions: the Moderating Effect of Job Opportunities. Operational Research and Management Journal, 6, 2, 57-78.

22. Hair, J.F., Anderson, R.E., Tatham, R.L., \& Black, W.C. (1998). Multivariate Data Analysis (5th Edition), Upper Saddle River: Prentice-Hall.

23. Holtom, B.C., Mitchell, T.R., Lee, T.W. \& Eberly, M.B. (2008). Turnover and Retention Research: A Glance at the Past, Review of the Present, and a Venture into the Future. The Academy of Management Annals, 1, 231-74.

24. Hom, P., Caranikas-Walker, F., Prussia, G., \& Griffeth, R. (1992). A meta-analytical structural equations analysis of a model of employee turnover. Journal of Applied Psychology, 77, 890-909.

25. Hu, L.T. \& Bentler, P.M. (1999). Cutoff criteria for fit indices in covariance structure analysis: conventional criteria versus new alternatives. Structural Equation Modeling, 6, 1-55.

26. Hulin, C., Raznowski, M., \& Hachiya, D. (1985). Alternative Opportunities and Withdrawal Decisions: Empirical and Theoretical Discrepancies and Integration. Psychological Bulletin, 97, 2, 233-250.

27. James, L.R., Mulaik, S.A. \& Brett, J.M. (2006). A tale of two methods. Organizational Research Methods, 9, 233-44.

28. Johnson, J.L. \& O'Leary-Kelly, A.M. (2003). The effects of psychological contract breach and organizational cynicism: Not all social exchange violations are created equal. Journal of Organizational Behavior, 24, 627-647.

29. Kanfer, R., Wanberg, C.R. \& Kantrowitz T.M. (2001). Job Search and Employment: A PersonalityMotivational Analysis and Meta-Analytic Review. Journal of Applied Psychology, 86, 5, 837-855.

30. Lee, T.W., Mitchell, T.R., Sablynski, C., Burton, J., \& Holtom, B.C. (2004). The effects of job embeddedness on organizational citizenship, job performance, volitional absences and voluntary turnover. Academy of Management Journal, 47, 711-722.

31. Lichtenstein, R., Alexander, J.A., McCarthy, J.F., \& Wells, R. (2004). Status Differences in CrossFunctional Teams: Effects on Individual Member Participation, Job Satisfaction, and Intent to Quit. Journal of Health and Social Behavior, 3, 322-335.

32. Lloyd, C. \& King, R. (2001). Work-related stress and occupational therapy. Occupational Therapy International, 8, 4, 227-243. 
33. Maertz, Jr. C. P. \& Griffeth, R. W. (2004). Eight Motivational Forces and Voluntary Turnover: A Theoretical Synthesis with Implications for Research. Journal of Management, 30, 667-683.

34. Marler, J.H., Fisher, S.L. \& Ke, W. (2009). Employee self-service technology acceptance: a comparison of pre-implementation and post-implementation relationships. Personnel Psychology, 62, 327-358.

35. Meyer, J.P., Allen, N.J., \& Smith, C.A. (1993). Commitment to Organizations and Occupations: Extension and test of a Three-Component Conceptualization. Journal of Applied Psychology, 78, 4, 538-551.

36. Miller, H., Katerberg, R., \& Hulin, C. (1979). Evaluation of the Mobley, Horner, and Hollingsworth model of employee turnover. Journal of Applied Psychology, 64, 509-517.

37. Mobley, (1977). Intermediate linkages in the relationship between job satisfaction and employee turnover. Journal of Applied Psychology, 62, 237-240.

38. Mobley, W., Horner, S., \& Hollingsworth, A. (1978). An evaluation of precursors of hospital employee turn-over. Journal of Applied Psychology, 63, 408-414.

39. Morrison, E.W. \& Robinson, S.L. (1997). When employees feel betrayed: A model of how psychological contract violation develops. Academy of Management Review, 22, 1, 226-256.

40. Mowday, R.T., Koberg, C.S., \& McArthur, A.W. (1984). The Psychology of the Withdrawal Process: A Cross-Validational Test of Mobley's Intermediate Linkages Model of Turnover in Two Samples. The Academy of Management Journal, (27)1, 79-94.

41. Orvis, K.A. Dudley, N.M., \& Cortina, J.M. (2008). Conscientiousness and Reactions to Psychological Contract Breach: A Longitudinal Field Study. Journal of Applied Psychology, 93, 5, 1183-1193.

42. Paillé, P. \& Grima, F. (2011). Citizenship and withdrawal in the workplace: Relationship between organizational citizenship behaviour, intention to leave current job and intention to leave the organization. The Journal of Social Psychology, 151, 4, 478-493.

43. Parzefall, M. R. \& Coyle-Shapiro, J. A. M. (2011). Making sense of Psychological Contract Breach. Journal of Managerial Psychology, 26, 1, 12-27.

44. Parzefall, M. R. \& Hakanen, J. (2010). Psychological contract and its motivational and health-enhancing properties. Journal of Managerial Psychology, 25, 1, 4-21.

45. Pate, J., Martin, G., \& Staines, H. (2000). Exploring the relationship between psychological contracts and organizational change: A process model and case study evidence. Strategic Change, 9, 8, 481-493.

46. Peters, L., Jackofsky E., \& Salter, J. (1981). Predicting turnover: A comparison of part-time and full-time employees. Journal of Occupational Behavior, 2, 89-98.

47. Pinder, C. C. \& Schroeder, K. G. (1987). Time to Proficiency following Job Transfers. The Academy of Management Journal, 30, 2, 336-353.

48. Phillips, J.J., \& Connell, A. O. (2003). Managing employee retention: A Strategic Accountability Approach. Burlington, MA: Elsevier.

49. Podsakoff, P.M., MacKenzie, S.B., Lee, J.-Y., \& Podsakoff, N.P. (2003). Common Method Biases in Behavioral Research: A Critical Review of the Literature and Recommended Remedies. Journal of Applied Psychology, 88, 879-903.

50. Robinson, S.L., Kraatz, M.S., \& Rousseau, D.M. (1994). Changing obligations and the psychological contract: A longitudinal study. Academy of Management Journal, 37, 1, 137-152.

51. Robinson, S.L. \& Morrison, E.W. (2000). The development of psychological contract breach and violation: A longitudinal study. Journal of Organizational Behavior, 21, 525-546.

52. Robinson, S.L. \& Rousseau, D.M. (1994). Violating the psychological contract: Not the exception but the norm. Journal of Organizational Behavior, 15, 245-259.

53. Rousseau, D.M. (1995). Psychological Contracts in Organizations: Understanding Written and Unwritten Agreements. Thousand Oaks: SAGE Publications.

54. Rugg, S. (2009). Junior occupational therapists' continuity of employment: What influences success? Occupational Therapy International, 6, 4, 277-297.

55. Sager, J.K., Griffeth, R.W., \& Hom, P.W. (1998). A Comparison of Structural Models Representing Turnover Cognitions, Journal of Vocational Behavior, 53, 254-273.

56. Schermelleh-Engel, K. Moosbrugger, H. \& Müller, H. (2003). Evaluating the fit of structural equation models: tests of significance and descriptive goodness-of-fit measures. Methods of Psychological Research Online, 8, 23-74.

57. Steel, \& Griffeth, R. W. (1989). The elusive relationship between perceived employment opportunity and turnover behavior: A methodological or conceptual artifact? Journal of Applied Psychology, 74, 846-864. 
58. Suazo, M.M. (2009). The mediating role of psychological contract violation on the relations between psychological contract breach and work-related attitudes and behaviours. Journal of Managerial Psychology, 24, 2, 136-160.

59. Sutton, G. \& Griffin, M.A. (2000). Transition from student to practitioner: The role of expectations, values and personality. British Journal of Occupational Therapy, 63, 380-388.

60. Turnley, W.H., Bolino, M.C., Lester, S.W., \& Bloodgood, J.M. (2003). The impact of Psychological contract fulfillment on the performance of In-Role and Organizational Citizenship Behaviors. Journal of Management, 29, 2, 187-206.

61. Turnley, W.H. \& Feldman, D.C. (1999). The impact of psychological contract violation on exit, voice, loyalty, and neglect. Human Relations, 52, 895-922.

62. Zhao, H., Wayne, S., Glibkowski, B. \& Bravo, J. (2007). The impact of psychological contract breach on work-related outcomes: a meta-analysis. Personnel Psychology, 60, 3, 647-680. 